\title{
IES
}

\section{PRODUCT MARKET REFORM AND INNOVATION IN THE EU}

Rachel Griffith
Rupert Harrison
Helen Simpson 


\title{
Product market reform and innovation in the EU
}

\author{
Rachel Griffith ${ }^{\dagger}$ \\ Rupert Harrison ${ }^{\ddagger}$ \\ Helen Simpson ${ }^{+}$
}

August 2006

\begin{abstract}
European Union countries have implemented widespread reforms to product markets in order to stimulate competition, innovation and economic growth. We provide empirical evidence that the reforms carried out under the EU Single Market Programme (SMP) were associated with increased product market competition, as measured by a reduction in average profitability, and with a subsequent increase in innovation intensity and productivity growth for manufacturing sectors. In our analysis we exploit exogenous variation in the expected impact of the SMP across countries and industries to identify the effects of reforms on average profitability, and the effects of profitability on innovation and productivity growth.
\end{abstract}

Keywords: Competition, Innovation, Productivity growth

JEL classifications: L1, O31, O47

Acknowledgements: We would like to thank Jonathan Haskel, Fabienne Ilkovitz, Steve Nickell, John Van Reenen and seminar participants at the European Commission, AIM and a CEPR conference at Trinity College Dublin for helpful comments. The analysis contained in this paper was funded by the European Commission, the ESRC and ESF under grant RES-000-23-0901 and the Advanced Institute of Management Research (AIM). All errors and omissions remain the responsibility of the authors.

\footnotetext{
† Institute for Fiscal Studies, University College London and AIM; rgriffith@ifs.org.uk

‡ Institute for Fiscal Studies, University College London and AIM; rharrison@ifs.org.uk

+ Corresponding author. Institute for Fiscal Studies and Nuffield College, Oxford; hsimpson@ifs.org.uk
} 


\section{Executive Summary}

Over the last twenty years EU member states and other OECD countries have implemented widespread reforms to product markets, aiming to stimulate competition and improve economic performance. Economic theory also suggests that changes in the degree of product market competition can influence innovative activity, and policy-makers in many EU countries have appealed to further competition-enhancing reforms as a way to raise rates of innovation and growth. In order to shed light on whether product market reforms are likely to help in achieving these goals, this paper investigates the impact that past reforms, in the form of the Single Market Programme (SMP), had on innovation activity in the EU.

The paper provides empirical evidence that the reforms carried out under the SMP were associated with increased product market competition, as measured by a reduction in average profitability, and with a subsequent increase in innovation intensity and productivity growth for manufacturing sectors. In our analysis we exploit exogenous variation in the expected impact of the SMP across countries and industries to identify the effects of reforms on average profitability, and the effects of profitability on innovation and productivity growth.

Our results have a bearing on the expected effects of possible future reforms, for example those being considered under the Lisbon Agenda. Our findings suggest that reforms that put pressure on firm profitability are likely to lead to increased innovation, all else equal. This suggests that such reforms could at least go some way towards increasing innovation intensity within the EU. 


\section{Introduction}

Over the last twenty years EU member states and other OECD countries have implemented widespread reforms to product markets, aiming to stimulate competition and improve economic performance. ${ }^{1}$ Economic theory also suggests that changes in the degree of product market competition can influence innovative activity, and policy-makers in many EU countries have appealed to further competition-enhancing reforms as a way to raise rates of innovation and growth. ${ }^{2}$ In order to shed light on whether product market reforms are likely to help in achieving these goals, this paper investigates the impact that past reforms, in the form of the Single Market Programme (SMP), had on innovation activity in the EU.

Our main contribution is to exploit variation in the timing and intensity of the Single Market Programme across industries and EU countries, and the fact that some countries were part of the EU while others were not, to provide exogenous variation in product market conditions. The use of these time varying, country-industry level indicators allows us to identify the impact of product market reforms from other changes in the economic environment.

In addition, we consider the effect of product market reforms on the level of available profits, or rents, to be the key channel through which they affect firms' incentives to innovate. This is in contrast to studies that relate product market reforms directly to outcomes. As well as being motivated by economic theory, our approach allows us to say something about the potential impact of future product market reforms on innovation and productivity growth; an important question in the context of the EU's Lisbon Agenda.

The SMP was a significant, large-scale programme of reforms carried out by EU member states in the early 1990s that included the removal of barriers to entry and regulatory barriers to trade. Extensive surveys and analysis carried out by the European Commission in advance of the implementation of the SMP identified industries and countries that were

\footnotetext{
${ }^{1}$ See Conway, Janod and Nicoletti (2005) for a discussion of recent reforms and Buigues et al (1990) for a discussion of earlier reforms.

${ }^{2}$ Lower rates of innovation and adoption of best practice technologies in EU countries are widely seen as reasons for lagging EU productivity growth. With this in mind, the European Council has set a target to raise R\&D investment to 3\% of the EU's GDP (the Barcelona target), and the Lisbon Agenda contains an aspiration to become "the most competitive and dynamic knowledge-based economy in the world" by the end of the current decade.
} 
expected to be affected by the reforms to different extents. We use this information to construct indicators of reform that vary differentially over time across countries and industries. We focus our empirical analysis on the manufacturing sector, as this is where the product market reforms undertaken as part of the Single Market Programme had the greatest impact, and where the majority of research and development (R\&D) is carried out. $^{3}$

Our findings suggest that the product market reforms associated with the SMP did lead to an increase in product market competition (as measured by a reduction in average profitability) in affected countries and industries. In turn we find that increased competition led to an increase in R\&D investment in manufacturing industries. Finally, we find evidence consistent with increased R\&D intensity being the primary route through which product market reforms translate into faster Total Factor Productivity (TFP) growth. However, we also find some evidence that the SMP may have had an additional direct and negative impact on R\&D intensity and TFP growth in some high-tech manufacturing industries with heavy reliance on public procurement.

This paper relates to two key strands in the empirical literature. First, there are a number of studies investigating the relationships between competition, innovation and productivity growth using firm-level data within a single country. These include the studies of Nickell (1996), Blundell, Griffith and Van Reenen (1999), and Aghion et al (2005a,b), which relate competition to innovation, and studies looking at the effects of trade liberalisation on productivity, for example, Aitken and Harrison (1999), Pavcnik (2002) and Javorcik (2004). These all use variation in product market conditions across industries within a country. ${ }^{4}$ In contrast, we use variation in institutions and reforms across countries.

Secondly, there is a small but growing literature investigating the impact of product market reforms using data across countries. Nicoletti and Scarpetta (2004) relate a large number of reforms to growth in TFP across OECD economies. They assume that product market reforms affect the rate of TFP convergence across countries and industries, and

\footnotetext{
${ }^{3}$ Network industries (telecommunications, post, electricity, water, gas, airlines and rail) also experienced substantial reforms. However, the nature of reforms and the processes driving innovation and technology transfer in these industries differ substantially from the rest of the economy and would required detailed modelling of each industry.

${ }^{4}$ Less related to our work is an empirical IO literature; for example, Bresnahan and Reiss (1990, 1991) and Berry (1992), where the emphasis is on entry in well defined, oligopolistic markets and on endogeneity of market structure, and Olley and Pakes (1996) which investigates the effects of deregulation on aggregate productivity growth and the underlying reallocation mechanism in one particular industry.
} 
find some evidence that the impact of reforms is larger for countries further behind the frontier. A key limitation of their analysis is that they only have time-varying measures of product market reforms for a small number of network industries. For the rest of the economy they use a single cross-section of regulation indicators for 1998, near the end of the sample period they consider. Alesina et al (2005) look at the impact of deregulation and privatisation on investment in a panel of network industries.

The structure of the paper is as follows. In the next section we describe our empirical methodology. Section 3 describes the data and provides a discussion of the indicators of product market reforms that we exploit in our empirical analysis, focusing on the sources of variation that allow us to identify the relevant economic relationships. In Section 4 we present our main results on the impact of product market reforms on innovation, and also examine effects on productivity growth. A final section summarises and concludes.

\section{Empirical strategy}

Our empirical approach follows from the theoretical literature on product market competition and growth, which emphasises the importance of economic profits, or rents, in providing incentives for firms to innovate. Increased competition may increase incentives for incumbent firms to reduce slack, ${ }^{5}$ or to innovate in order to protect or enhance their market position (i.e. to escape competition). ${ }^{6}$ However, increased competition may also reduce the rewards to innovation or entry into a market, and thus discourage these activities. ${ }^{7}$ The role of economic profits has also been emphasised in the existing empirical literature, for example, Nickell (1996) and Aghion et al (2005a,b).

Product market reforms can affect competition through the intensity with which firms interact in the product market and through lowering the costs of entry. In equilibrium the level of rents will reflect both these factors. Competitive intensity between firms will drive prices down, while entry, or the threat of entry, will restrain firms from raising prices. In our empirical analysis we start from the premise that the primary impact of product market

\footnotetext{
${ }^{5}$ See for example, Hart (1983) and Schmidt (1999).

${ }^{6}$ See, inter alia, Gilbert and Newbury (1982), Aghion et al (1997), Aghion et al (2001), and Aghion et al (2005a).

${ }^{7}$ This 'Schumpeterian effect' is at work in the growth models of Aghion and Howitt (1992) and Grossman and Helpman (1991) and can be seen in models of rent dissipation, for example, Arrow (1962) and Tirole (1998).
} 
reforms on innovation is through their effect on rents, i.e. the potential rewards from innovation.

The two equations given in (1), describe the general relationship between product market reforms (PMR), the extent of product market competition (captured by the average level of profitability, $\mu$ ), and innovation (innov).

$$
\begin{aligned}
\mu_{i j t} & =f\left(P M R_{i j t}, X_{i j t}\right), \\
\text { innov }_{i j t} & =g\left(\mu_{i j t}, X_{i j t}\right),
\end{aligned}
$$

where $i$ indexes industry, $j$ country, $t$ time and $X$ is a vector of other factors influencing these relationships. Our key identifying assumption is that we exclude most, or all, of our indicators of product market reforms from the innovation equation. We test the empirical validity of our exclusion restrictions, i.e. we test for direct effects of product market reforms on innovation, and we compare the results using the restricted model with those of an unrestricted reduced form.

Our main empirical model thus takes the form of a two-stage instrumental variables specification, where we are interested in the estimated relationship in both stages. We assume a linear functional form for both equations. We begin by examining the relationship between product market reforms and the degree of product market competition as measured by the average level of profitability, given by:

$$
\mu_{i j t}=P M R_{i j t} \beta_{P M R}+\alpha_{i t}+\eta_{j t}+e_{i j t}
$$

where $\mu_{i j t}$ is the average level of profitability (defined below) and $P M R_{i j t}$ is a vector of indicators of product market reforms. We also include a full set of both industry-time dummies, $\alpha_{i t}$, and country-time dummies, $\eta_{j t}$. These control for industry-time specific and country-time specific unobservable factors that may be correlated with product market reforms. The parameters of interest are the $\beta$ coefficients on the product market reforms. The inclusion of industry-time and country-time dummies means that the $\beta$ coefficients are identified using differential variation over time within industries, within countries. If product market reforms are associated with increased competition (i.e. lower average profitability) we would expect these $\beta$ coefficients to be negative. 
Equation (2) is used as the first-stage reduced-form in an instrumental variables estimation of the second-stage equation which characterises the relationship between competition and innovation:

$$
\text { innov }_{i j t}=\beta_{\mu} \mu_{i j t}+\alpha_{i t}+\eta_{j t}+u_{i j t} .
$$

The level of competition is unlikely to be the single major determinant of innovation in a country or industry. Factors such as infrastructure, skills and technological opportunity may play a much more important role, and we again include a full set of industry-time and country-time dummies in the second stage equation.

To re-emphasise, we expect the immediate impact of product market reforms to be on the degree of product market competition that firms face, which we summarise in our measure of the average level of profitability. This in turn would be the main channel through which product market reforms affect innovation incentives. This leads to our exclusion restrictions - product market reforms do not directly enter equation (3). We test for any direct effects of product market reforms on innovation, as well as the indirect effect through their impact on the level of rents. ${ }^{8}$

As a final exercise we investigate effects of product market reforms on productivity growth on the basis that their main effect is to put pressure on firms to innovate and imitate. We estimate an equation that relates the growth rate of TFP to the intensity of innovation, following the approach of Griliches (1979) and others. As before we estimate this by instrumental variables where the excluded instruments are our measures of product market reforms,

$$
\Delta T F P_{i j t}=\beta_{I} \text { innov }_{i j t-1}+\lambda_{1} \mu_{i j t-1}+\lambda_{2} D T F_{i j t-1}+\alpha_{i t}+\eta_{j t}+\varepsilon_{i j t} .
$$

In the simplest specification we exclude the average level of profitability from the TFP growth equation $\left(\lambda_{1}=0\right)$. As before, we test the validity of this restriction. However, it is possible that product market competition increases productivity directly by forcing firms to increase their productive efficiency. We therefore consider a more general model where we include measures of both innovation and average profitability and instrument these two variables with the product market reforms. In all specifications we also include a measure

\footnotetext{
${ }^{8}$ This is in contrast to, for example, Nicoletti and Scarpetta (2003). That paper aggregates product market reforms into a single index, giving indicators equal weight. In this paper we use the estimated impact of product market reforms on rents as a way of aggregating the reforms.
} 
of the distance to the technological frontier at the country-industry-year level $D T F_{i j t-1}$ capturing a country's scope for technological catch-up, (measured by the difference in TFP with respect to the leading country within industry and year), ${ }^{9}$ and industry-time and country-time dummies. We test for potential direct effects of product market reforms on productivity growth, for example through the reallocation of resources towards more productive firms or activities.

It is likely that the error terms in equations (2), (3) and (4) exhibit some degree of autocorrelation. To allow for this our main results use Newey-West standard errors with a maximum lag length of 3 periods, and we test that our results are robust to clustering the standard errors at the country-industry level.

\section{Data}

We use measures of product market regulations and reforms, average profitability, innovation activity and productivity growth. We discuss these in turn. Our sample consists of an unbalanced panel of nine countries, (listed in Table 2), and 12 two-digit manufacturing industries over the period 1987-2000, for which we have data on all these variables.

\subsection{Product market regulations and reforms}

One of the main challenges in trying to identify the impact of product market competition on innovation is the endogeneity of competition - there may be reverse causality, with innovation affecting competitive conditions, and there may be omitted factors that are correlated with both innovation and competition. Product market reforms can provide useful exogenous variation and enable us to identify the causal impact of competition on innovation. In order to be useful, the reforms must have had sufficient variation, within countries and industries, over time. In addition, the effect of specific policies may be of direct interest to policy makers.

The indicators of product market reforms that we use are based on the implementation of the European Single Market Programme (SMP) in the early 1990s. This was a large scale

\footnotetext{
${ }^{9}$ See Cohen and Levinthal (1989), Aghion and Howitt (1998), Howitt (2000) and Griffith, Redding and Van Reenen (2004) for examples of research that emphasises the role of absorptive capacity and distance to the technological frontier.
} 
project by the then members of the European Union to reduce internal non-tariff barriers to trade and other barriers to the free movement and factors of production across borders. The SMP was a large reform, and it was undertaken across a number of countries. It was, however, undertaken at around the same time across countries. This means that to identify the impact of the SMP from other contemporaneous macroeconomic effects (for example, the recession of the early 1990s in many European countries) we need to either include countries that were not involved in SMP as a control group, or use variation in the impact it had across different industries. We do both of these. We use the differential impact of the SMP across industries and countries as a source of exogenous variation in product market conditions, and include a control group of unaffected countries.

Our data on the SMP is from a European Commission report by Buigues et al (1990). ${ }^{10}$ This is based on information contained in the 1988 Cecchini Report and other sources, including an extensive survey of businesses in the participating countries. The report identifies 3-digit industries that were expected ex-ante to be highly and moderately affected by the SMP, as well as the share of each of these industries in each country's manufacturing employment over 1985-1987. ${ }^{11}$ The researchers identified a common list of industries across all SMP countries, and then asked national experts from each country to add or remove sectors from the list according to whether the effects of the SMP were expected to be large or small in each sector in their country. Thus, for example, a sector would be removed from the list if it were already very open to international competition before the implementation of the SMP. Examples of such sectors include the aerospace industry in the UK and the brewing and malting industry in Denmark.

There are therefore two sources of variation across SMP countries in the ex-ante expected impact of the SMP. First, the identified 3-digit sectors make up different shares of employment across countries in the 2-digit industries in our sample. A limitation of the analysis is that some of this variation may not be exogenous with respect to the outcomes we are measuring. However, much of the variation reflects longstanding differences in the share of particular activities in countries' manufacturing activity. Second, the fact that some sectors have been removed from the list at the country level creates further variation

\footnotetext{
${ }^{10}$ Aspects of this data have been used in various studies, including Mayes and Hart (1994), and Allen, Gasiorek and Smith (1998). We are not aware of any studies using the detailed industry-level data across several SMP countries.

${ }^{11}$ This information is contained in Table 26 in the Report's statistical annex.
} 
in the expected effects of the SMP across SMP countries. This variation stems from the fact that some countries had higher barriers to competition in some sectors than others at the start of the period.

As well as variation across SMP countries, our main results also use non-SMP countries as controls for the impact of the SMP. This introduces a third source of variation in the data. However, we may be concerned about the suitability of non-SMP countries as controls for what would have happened in the SMP countries. We test the robustness of our main results to dropping non-SMP countries from the sample using only the first and second sources of variation described above.

The sectors affected by the SMP fall into four main groups. Three of these were expected to be highly affected. The first is a group of "high-technology public procurement sectors" including telecommunications equipment, office machinery and medical and surgical equipment. The second and third are designated as "traditional public-procurement and regulated markets" and are split by the degree of measured price dispersion across countries prior to the SMP. The high price-dispersion group includes, amongst others, pharmaceutical products, and brewing and malting, while the low price dispersion group is dominated by shipbuilding and electrical machinery. Finally there is a fourth group of sectors that were expected to be moderately affected by the SMP, and which includes a range of consumer, investment and intermediate goods.

We allow the estimated effects of the SMP to vary across these four groups of sectors. Table 1 shows the average share of each 2-digit industry in our sample that fell into each of the four groups in 1986, the year before the beginning of our sample period. These four variables across countries and industries are the instruments that we use in our empirical results, and in each case take the form of a step-function that is equal to zero in all years prior to 1992 and then rises in 1992 and all subsequent years to the country-industry specific share affected. The table shows that the first group of highly affected sectors are concentrated in the machinery and equipment industry, while the other groups are spread across a range of industries. Group 4 contains the most variation across industries, and this group contributes much of the explanatory power of our instruments. Only three of the twelve industries contain no affected sectors. In addition, as discussed above, non-SMP countries contain no affected sectors by definition, so the values of the instruments are equal to zero in all years in all industries in these countries. 
[Table 1 here]

We also explored the possibility of using another source of variation, which comes from the rate at which EU countries implemented the SMP. This information is contained in the transposition deficit, first published by the EU in 1997. On this basis we can group our SMP countries into two groups - three SMP countries with low values of the deficit (the UK, the Netherlands and Denmark) and two SMP countries with slightly higher values (France and Belgium). We experimented with refining our measures by multiplying all our instruments by the percentage of EU directives that were transposed into national law by each country by 1997 (i.e. we assume that 92.6\% of all directives are implemented in France, and $96.5 \%$ in the UK). Using this additional source of variation leaves our results effectively unchanged, suggesting that this source of variation has little additional power in explaining average levels of profitability.

\subsection{Average profitability}

As discussed above, the main channel through which product market reforms are expected to affect innovation outcomes is the level of rents, or economic profits, in the market. This is not straightforward to measure. We construct a measure of the average level of profitability at the country-industry level for manufacturing industries using the OECD STAN database, which provides information at the two-digit industry level on valueadded, labour and capital stocks. Boone (2000) shows that this measure of competition is preferred to most other commonly used measures. It is more theoretically robust, particularly than those based on market concentration and market shares, and it is the only commonly-used measure of competition that is available across countries.

Our measure of average profitability is value-added as a share of labour and capital costs:

$$
\text { profit }_{i j t}=\frac{\text { ValueAdded }_{i j t}}{\text { LabourCosts }_{i j t}+\text { CapitalCosts }_{i j t}},
$$

where all variables are in nominal prices. This simple measure can be shown to be equivalent to the measure proposed by Roeger (1995), and is equivalent to the price-cost margin or mark-up under the assumption of constant returns to scale, such that marginal 
cost is equal to average cost. ${ }^{12}$ To the extent that there are increasing (decreasing) returns to scale this measure will be biased downwards (upwards) compared to the true mark-up that firms charge. While value-added and labour costs are observed in the data, capital costs are not. We construct a perpetual inventory measure of the capital stock using data on investment. For countries where capital deflators are not available we use cross-country averages of those that are available. We calculate the cost of capital assuming that capital flows freely across borders so that all countries face a world interest rate, for which we use the US long-term interest rate. In our main results we instrument average profitability with exogenous changes in competition, which should help to control for classical measurement error.

Assuming that all countries face the same world interest rate might induce bias in the results if some countries have liberalised their credit markets during the period in a way that is correlated with reforms to product markets. We check the sensitivity of our main results to the alternative assumptions of closed capital markets or a constant cost of capital across countries. The results are not very sensitive to different ways of constructing the cost of capital, and the main conclusions are robust to these alternatives.

Column (1) of Table 2 shows the mean and standard deviation of the profitability variable across manufacturing industries and time for each country in our sample, (we discuss the remaining columns in Section 3.3). There is wide, and sometimes surprising, variation in the average level of profitability across countries. For example, on average the US has one of the highest levels, which runs counter to our intuition about the degree of competition in the US and Europe. There are various data incompatibilities in the measurement of capital and value-added across countries that affect the cross-section variation in the average level of profitability. For this reason it is important that we include country-time dummies when we estimate equation (2). Note that, as stressed above, our results are based on time-series variation in profitability within country-industries.

[Table 2 here]

The second perhaps surprising feature of measured profitability is that it appears to trend upwards over time for most countries. At first this may seem to conflict with most

\footnotetext{
${ }^{12}$ See Klette (1999) for a discussion. We use a measure of the mark-up over value added rather than over sales for reasons of data availability, but the results are not affected by using the mark-up over sales for those observations where both are available.
} 
preconceptions about changes to the degree of competition associated with product market reforms, globalisation and opening to trade. This has been noted in the literature, and one explanation, discussed in Blanchard and Giavazzi (2003) and Boulhol (2004), is that upward trending measured rents could be a short term response to reductions in the bargaining power of workers. ${ }^{13}$ There are a range of other factors that might explain upwards trending profitability over time, including increases in returns to scale. However, what is important from our point of view is that differential changes in profitability across countries and industries can be shown to be related to product market reforms in ways that accord with theory. We discuss this further in the results section.

Another feature of our measure of profitability is that it is generally pro-cyclical. We include country-time dummies in all regressions to control for this. We might be concerned that this will not remove all of the cyclical variation in profitability. However, any excess pro-cyclicality in profitability would be likely to induce a positive bias in our OLS estimates. For example, if R\&D or productivity growth is pro-cyclical, excess cyclicality in average profitability could bias the coefficient on profitability in a positive direction, which means that the size of our results would be understated (we find negative coefficients on average profitability). In addition, when we instrument profitability with our indicators of product market reforms, the estimated coefficient becomes more negative in almost all cases. This is consistent with the possibility that the IV estimates control for measurement error in profitability that is associated with excess cyclicality.

\subsection{Measuring innovative activity and total factor productivity growth}

Our main measure of innovation activity is Business Enterprise R\&D (BERD) expenditure from the OECD ANBERD database. There is substantial variation in business sector R\&D intensity both across and within countries. For example, between 1981 and 2001 BERD as a percentage of GDP in Finland increased by over 1.5 percentage points, whereas in the UK it actually decreased by 0.25 percentage points. In our empirical analysis we use these data at the country-industry-year level. Columns (2) and (3) of Table 2 show the means and standard deviations for the two indicators of innovation activity that we use in our

\footnotetext{
${ }^{13}$ The intuition is that declining bargaining power reduces the share of rents captured by workers as higher wages, and increases the share that is measured in firms' profits. In the long term, the increase in profitability associated with declining workers' bargaining power would be expected to lead to entry and a reduction of rents to their previous level, but to the extent that these effects occur with lags it is possible for the rent transfer effect to dominate the entry effect during the transition period.
} 
analysis: R\&D intensity, R\&D expenditure as a percentage of value-added, which is our main measure; and log real R\&D expenditure which we use as a robustness check.

We measure the growth of total factor productivity growth using a superlative index (Caves et al, 1982a,b). The data come from the OECD STAN database, which provides information at the two-digit industry level on value-added, labour and capital stocks. The growth rate of TFP for a country-industry is defined as

$$
\Delta T F P_{i j t}=\ln \left(V_{i j t} / V_{i j t-1}\right)-\tilde{\alpha}_{i j t, t-1} \ln \left(L_{i j t} / L_{i j t-1}\right)-\left(1-\tilde{\alpha}_{i j t, t-1}\right) \ln \left(K_{i j t} / K_{i j t-1}\right),
$$

where $V$ denotes real value-added (converted to US dollars using an economy-wide PPP), $\tilde{\alpha}_{i j t, t-1}$ is the average labour share over $t$ and $t-1$,

$\tilde{\alpha}_{i j t, t-1}=\frac{1}{2}\left(\alpha_{i j t}+\alpha_{i j t-1}\right)$,

$L$ is numbers employed and $K$ is capital stock (converted to US dollars using an economywide PPP). One concern that is often expressed in the literature is that the measured share of labour in value-added can be quite volatile. This is suggestive of measurement error, so we check that our main results are robust to the adjustment suggested by Harrigan (1997). This involves exploiting the properties of the translog production function to smooth the observed labour shares. ${ }^{14}$ The final column of Table (2) provides descriptive information on our TFP growth measure.

As a robustness check we also construct a measure of TFP growth that allows for imperfect competition following Hall (1988) and Roeger (1995). It is well known that imperfect competition can lead to bias in measured TFP. In the presence of positive markups, measured TFP growth will be biased upwards or downwards depending on whether capital per worker is increasing or decreasing over time. In the empirical section we show that our results are not significantly affected by adjusting our TFP measure for the presence of positive mark-ups.

\footnotetext{
${ }^{14}$ Under the assumption of a translog production function and standard market-clearing conditions, the labour share can be expressed as a function of the capital-labour ratio and a country-industry constant. If actual labour shares deviate from their true values by an i.i.d. measurement error term, then the parameters of this equation can be estimated by fixed effects panel data estimation, where we allow the coefficient on the capital-labour ratio to vary across industries $j$. The fitted values from this equation are then used as the labour cost shares in our calculation of TFP growth.
} 


\section{Empirical results}

We now turn to our empirical results. We first discuss the impact of product market reforms on product market competition and $R \& D$, including a number of robustness checks. Then in section 4.2 we discuss our results for productivity growth.

\subsection{The impact of product market reforms on $R \& D$}

We start by considering the relationship between product market reforms and profitability, the first stage of the IV estimation, in Table 3. In column (1) we include separate country dummies, industry dummies and time dummies. In column (2) we include country-time and industry-time dummies, meaning that we identify the coefficients of interest on the indicators of product market reform from variation in these indicators over time within country-industries. We see that each of the four SMP indicators is associated with lower profitability, and that this relationship appears stronger in the more highly affected sectors (SMP groups 1 to 3), though is only statistically significant in the cases of groups 2 and 4. ${ }^{15}$ The partial $\mathrm{R}^{2} \mathrm{~s}$ and F-tests at the bottom of the Table show that the instruments have explanatory power. For example the value of the F-statistic for the four SMP variables in column (2) is above the critical values for the test of weak instruments provided by Stock and Yogo (2004).

\section{[Table 3 here]}

In column (3) we repeat the specification in column (1) but include only SMP countries in the estimation sample. This removes one source of variation in our data - the use of nonSMP countries as a control group. Thus we are attempting to identify the effects of the SMP purely from variation across participant countries in the expected impact of the SMP on affected industries. The main effect on the results is that we no longer find a significant effect on profitability from the group 2 sectors. However, a strong negative impact from the moderately affected sectors, group 4, remains and provides most of the explanatory power. As can be seen in Table 1, a number of industries are categorised as moderately affected sectors, providing substantial variation in our data. However, the F-test and

\footnotetext{
${ }^{15}$ In our main results we use Newey-West standard errors with the maximum lag length set to three periods to allow for serial correlation in the error term. In addition the results are generally robust to clustering the standard errors by country-industry to allow for arbitrary correlation within country-industries. For example, the standard error on SMP group 2 in column (1) of Table 3 increases from 0.110 to 0.164 in this case, while that on SMP group 4 increases from 0.032 to 0.039 .
} 
partial $\mathrm{R}^{2}$ are significantly lower than in the first two columns, indicating the possibility of weak instruments when we restrict the sample to the SMP participant countries.

We now turn to the relationship between competition and innovation in Table 4 where $R \& D$ intensity is the dependent variable. In the OLS specification in column (1) we find a small effect of competition (lower profitability) on R\&D intensity. Column (2) shows IV results, which indicate a much stronger relationship between increased competition and innovation. This suggests an upwards bias in the OLS results, for example due to reverse causality from R\&D intensity to profitability, or possibly as a result of attenuation bias. However, the Hansen J test of over-identifying restrictions (i.e. whether the SMP variables can be excluded from the R\&D regression) is rejected in this specification. This is due to a direct negative effect of the SMP on R\&D in group 1 sectors, as shown in column (3).

Buigues et al. (1990) say the group 1 activities "are characterised by considerable economies of scale which are not always properly exploited at Community level, and by large $R \& D$ budgets in which the lack of cooperation between European companies constitutes a handicap" (p. 23). This raises the possibility that consolidation and rationalisation across countries in these sectors following the SMP may have reduced R\&D expenditure.

\section{[Table 4 here]}

In column (4) we examine the direct reduced form impact of the SMP variables on innovation. We see that the coefficients are roughly consistent with the two-stage IV results. For example, combining the coefficient of -0.137 on the moderately affected sectors (group 4) in column (2) of Table 3 with the coefficient of -0.452 on profitability in column (3) of Table 4 suggests an indirect impact on R\&D intensity of about 0.06 , which is close to the direct estimated impact of 0.063 in column (4) of Table 4.

What do these results imply about the economic magnitude of our estimated effects? The coefficient on profitability in column (3) of Table 4 suggests that a one percentage point fall in profitability is associated with on average about a 0.45 percentage point increase in R\&D intensity. Consider the impact of the SMP on the chemicals industry in the UK, for example, one of the most highly affected industries in the sample. 30\% of the industry fell into Group 2 of highly affected sectors, while a further 39\% of the industry fell into Group 4 of moderately affected sectors. Combining these numbers with the coefficients on the SMP variables in column (2) of Table 3, our estimates predict that the SMP was 
associated with average profitability in the sector that was 16 percentage points lower than in the absence of the SMP. In fact the average level of profitability in the sector in the UK only fell by about 1 percentage point over the period, but this is in stark contrast to the increases experienced in some other non-SMP countries such as Finland and the US, where average profitability in the sector rose by 15 and 13 percentage points respectively. Combining this effect with the coefficient on profitability in column (3) of Table 4 suggests that the SMP was associated with $R \& D$ intensity that was 7.3 percentage points higher than in the absence of the SMP. We can compare this to the reduced form coefficients on the SMP variables in column (4) of Table 4, which also generate a predicted increase in $R \& D$ intensity of 7.3 percentage points. The actual increase in $R \& D$ intensity in the industry over the period was just over 10 percentage points (from $12.4 \%$ in 1987 to $22.8 \%$ in 2000). Thus, while many other factors may have affected R\&D intensity in this industry in the UK over the period, both our IV and reduced form estimates suggest that in the absence of the SMP it would have increased by far less than it did.

\subsubsection{Robustness}

Table 5 shows our first robustness check using log real R\&D expenditure instead of R\&D intensity. We do this to ensure that our results are not driven by the impact of the SMP on output (i.e. the denominator of R\&D intensity). The results support those in Table 4 using R\&D intensity. We start in column (1) with OLS results. In column (2) we use all four SMP variables as excluded instruments. The Hansen J-test rejects the over-identifying restrictions, and in column (3) we see that, we again cannot exclude a direct effect of the SMP on log real R\&D expenditure in group 1 sectors. As before, the estimated coefficient on profitability becomes significantly more negative in the IV specification. Column (4) contains the reduced form.

\section{[Table 5 here]}

We next test the robustness of the relationships estimated above to using only the sample of SMP countries. The results above use non-SMP countries as controls, as well as variation in the effects of the SMP across industries in the SMP countries. In Table 6 we show equivalent results using only the SMP countries, thus using only the latter form of variation. We use the first stage IV estimation from column (3) of Table 3 discussed above. The key result is that the estimated coefficient on profitability in column (3) of Table 6 is similar to that in Table 4. Note that in column (2) with the full set of 
instruments the Hansen $\mathrm{J}$ test rejects the over-identifying restrictions. When we include SMP Group 2 (traditional public procurement and regulated markets, high price dispersion) directly in column (3), the over-identification test no longer rejects. This is consistent with the reduced form results in column (4) and the first stage results in column (3) of Table 3; the SMP is positively associated with R\&D intensity in Group 2 sectors within the participant countries, but not negatively associated with the level of profitability. Thus, when we restrict the sample to participant countries, the hypothesis that the only effect of the SMP on innovation in these industries is through its impact on profitability is rejected by the data. This was not the case in Table 4 when we included non-SMP countries as controls.

A number of other features of the results in Table 6 are worth noting. First, the reduced form coefficients in column (4) are very similar to those in Table 4 for Groups 1 and 4, but we no longer find evidence of a direct negative impact of the SMP on R\&D intensity in group 1, and there is no evidence of a positive impact in Group 3. In addition, the Fstatistics and partial $R^{2} s$ in columns (2) and (3) suggest that the instruments are fairly weak when we remove the additional variation provided by non-SMP countries. However, the estimated coefficient on profitability is very similar to that in Table 4, suggesting that any weak instruments bias may be fairly small in this case.

[Table 6 here]

\subsection{Product market reforms and productivity growth}

Finally, we briefly consider the effect of product market reforms on productivity growth through their effect on $R \& D$, and examine whether there is any evidence for a direct effect of the degree of product market competition productivity growth. ${ }^{16}$

In columns (1) and (3) of Table 7, which show OLS specifications, we find a positive association between R\&D intensity and TFP growth and between competition (lower profitability) and TFP growth. We also include a measure of industries' distance to the technological frontier and find that country-industries that are further from the frontier experience faster TFP growth. This is consistent with productivity convergence, for example if countries further behind the frontier are more able to benefit from imitation and

\footnotetext{
${ }^{16}$ Note that the sample is slightly smaller than above because we lose the first year of data. This is because the independent variables are all lagged by one period.
} 
adoption of technologies developed near to the frontier. In columns (2) and (4) we instrument R\&D intensity and profitability with our SMP indicators, (the reduced forms are similar to those in column (2) of Table 3 and column (4) of Table 4.) The IV estimates of the impact of R\&D on TFP growth (column (4)) are significantly larger than the OLS estimates, while the IV estimate of the impact of profitability is not significant. ${ }^{17}$ Finally column (5) presents the reduced form impact of the instruments on TFP growth.

A number of features of these results are worth noting. First, the results in column (2) suggest that product market reforms associated with the SMP raised productivity growth through their impact on R\&D intensity. However, it is not immediately clear why the IV coefficient on R\&D intensity in column (2) should be significantly larger than the OLS coefficient. One possibility is measurement error in $R \& D$, but this is unlikely to account for such a large OLS bias. Another possible explanation is that the IV estimate in column (2) corresponds to a local average treatment effect (LATE) in the context of heterogeneous returns to $R \& D$ across industries. ${ }^{18}$ For example, if the average rate of return to $R \& D$ is significantly higher in those industries where our instruments display most variation, this could explain why the IV estimate of the coefficient on R\&D intensity is larger than the OLS estimate. ${ }^{19}$ This would be problematic if our aim was to use our instruments to estimate the average effect of $R \& D$ on productivity growth across all sectors. However, given that we are interested precisely in the impact that the SMP had on productivity growth in affected sectors through its impact on $R \& D$, a local average treatment effect is exactly the parameter of interest in this case.

Secondly, the results in column (4) suggest that there is no significant direct impact of profitability on productivity growth once profitability is instrumented with the SMP indicators. However, the F-statistic suggests that the instruments may be too weak to

\footnotetext{
17 The results are very similar using our measure of TFP growth adjusted for imperfect competition. For example the estimated coefficient (standard error) on R\&D intensity in column (4) is equal to $0.829(0.264)$ while the coefficient (standard error) on profitability is equal to $0.125(0.095)$.

${ }^{18}$ In the context of heterogeneous returns across industries, an IV estimate can be interpreted as a weighted average of the returns in the sample, where the "weights" are the relative size of the increment in the endogenous variable induced by the instruments. See Imbens and Angrist (1994) for a discussion of LATE estimates, or Card (2001) for a discussion in the context of the returns to education.

${ }^{19}$ To investigate this possibility we split the sample into country-industries where our instruments display variation over time and those where they do not. The former group contains 394 out of 1008 observations. The coefficient (standard error) on R\&D intensity for this sample is 0.235 (0.050), while the coefficient (standard error) in the latter group is -0.001 (0.039). The fact that the coefficient is significantly higher in those industries where our instruments display variation is consistent with a local average treatment effect interpretation of the difference between the OLS and IV estimates.
} 
separately identify both the impact of profitability and R\&D intensity, so this result may not be robust.

Finally, the reduced form estimates in column (5) find a direct positive effect of the SMP on productivity growth only in Group 2 of highly affected industries. In line with our findings on R\&D intensity there is also evidence of a direct negative effect of the SMP in high-tech public procurement sectors (Group 1).

What is the economic magnitude of these effects? The coefficient on R\&D intensity in column (2) of Table 7 suggests that a 1 percentage point increase in $R \& D$ intensity is associated with about a 0.6 percentage point increase in TFP growth. ${ }^{20}$ As an example, the size of this effect is similar to the predicted impact of the SMP on the metal products industry in the UK: 7.5\% of the industry fell into Group 2 of highly affected sectors, and the coefficient on SMP Group 2 in column (4) of Table 4 is 0.163, suggesting that the SMP program was associated with a 1.2 percentage point increase in $R \& D$ intensity in the industry as a whole. This in turn was associated with about a 0.7 percentage point increase in TFP growth. ${ }^{21}$ The actual average increase in TFP growth in the metal products industry was 1.7 percentage points, from $2.5 \%$ to $4.2 \%$, so the predicted impact of the SMP can explain just over one third of this. These seem plausible effects.

\section{$5 \quad$ Summary and conclusions}

In this paper we have presented evidence that suggests that the EU Single Market Programme reduced the average level of profitability in those industries and countries that were affected, and that this had a positive impact on innovative activity in these industries and countries, which in turn affected total factor productivity growth. These relationships accord well with economic theory.

We interpret the results on profitability as indicating that the Single Market Programme implemented product market reforms that reduced the extent to which firms could charge prices above costs (and so reduced profitability). This is supported by our evidence. If the main impact of the SMP was instead through reductions in input costs, then the impact

\footnotetext{
${ }^{20}$ Following Griliches (1979) we could also interpret this as suggesting that the social rate of return to R\&D is about $60 \%$, assuming that spillovers occur only within industries. This is similar to other estimates in the literature.

${ }^{21}$ This is 0.012 times the coefficient on R\&D intensity in column (2) of Table 7 of 0.598.
} 
would be expected to be felt across all industries, and not concentrated in those industries highlighted in the Buigues et al. report.

Our results have a bearing on the expected effects of possible future reforms, for example those being considered under the Lisbon Agenda. Our findings suggest that reforms that put pressure on firm profitability are likely to lead to increased innovation, all else equal. This suggests that such reforms could at least go some way towards increasing innovation intensity within the EU.

However, it is important to note that many other factors are also likely to have affected innovative activity and productivity growth over the period we have considered. These include human capital, infrastructure (broadly defined), and a range of other institutional factors. These may interact with product market conditions - for example, poorly functioning financial markets may restrict firms' ability to respond to increased competition. The role of credit and labour market regulations, and other institutions, in determining the impact of reforms to product markets would be an interesting topic for further research. 


\section{References}

Aghion, P., Bloom, N., Blundell, R., Griffith, R. and P. Howitt (2005a) "Competition and Innovation: An Inverted U Relationship”, Quarterly Journal of Economics, Vol. 120, No. 2, pp. 701-728.

Aghion, P., Blundell, R., Griffith, R., Howitt, P., and S. Prantl (2005b): "The Effects of Entry on Incumbent Innovation Productivity ", CEPR Discussion Paper 5323

Aghion, P., Harris, C., and J. Vickers (1997), "Competition and Growth with Step-by-Step Innovation: An Example”, European Economic Review, Papers and Proceedings, pp. 771-782.

Aghion, P., Harris, C., Howitt, P. and J. Vickers (2001), "Competition, Imitation and Growth with Step-by-Step Innovation", Review of Economic Studies, vol 68, pp. 467-492.

Aghion, P. and Howitt, P. (1992) "A Model of Growth Through Creative Destruction" Econometrica, 60, 323-351

Aghion, P., and P. Howitt (1998) Endogenous Growth Theory. Cambridge, MA: MIT Press.

Aitken, B. J. and Harrison, A. E. "Do Domestic Firms Benefit from Direct Foreign Investment? Evidence from Venezuela.” American Economic Review, June 1999, 89(3), 605-618.

Alesina, A., Ardagana S., Nicoletti G. and F. Schiantarelli (2005) "Regulation and Investment” Journal of the European Economic Association, June 2005, Vol 3, Issue 4.

Allen, C., Gasoriek M. and A. Smith (1998), "European Single Market: how the programme has fostered competition”, Economic Policy, October.

Berry, S. (1992) "Estimation of a Model of Entry in the Airline Industry”, Econometrica, 60, 889-917

Blanchard, O. and F. Giavazzi (2003), "Macroeconomic effects of regulation and deregulation in goods and labour markets", Quarterly Journal of Economics, August 2003.

Blundell R., Griffith R. and J. Van Reenen (1999) "Market Share, Market Value and Innovation in a Panel of British Manufacturing Firms" Review of Economic Studies, (1999) 66, 529-554.

Boone, J. (2000) “Measuring Product Market Competition”, CEPR Working Paper 2636.

Boulhol (2005), Pro-competitive policies and the convergence of mark-ups, Université Paris I Panthéon-Sorbonne, mimeo.

Bresnahan, T. and Reiss, P. (1990) "Entry in Monopoly Markets", Review of Economic Studies, 57(4), 531-53.

Bresnahan, T. and Reiss, P. (1991) "Entry and Competition in Concentrated Markets”, Journal of Political Economy, 99(5), 977-1009.

Buigues, P., F. Ilzkovitz and J. F. Lebrun (1990) "The impact of the internal market by industrial sector: the challenge for member states”, European Economy, Special Issue

Card, D. (2001), "Estimating the Return to Schooling: Progress on Some Persistent Econometric Problems”, Econometrica, 69(5), 1127-1160

Caves, D. W., Christensen, L. R. and Diewert, W. E. (1982a) "Multilateral Comparisons of Output, Input, and Productivity Using Superlative Index Numbers.” Economic Journal, 92, March, 73-86.

Caves, D. W., Christensen, L. R. and Diewert, W. E. (1982b) "The Economic Theory of Index Numbers and the Measurement of Input, Output, and Productivity." Econometrica, 50(6), 1393-1414.

Cohen and Levinthal (1989) "Empirical Studies of Innovation and Market Structure," in Handbook of Industrial Organization, eds R. Schmalensee and R.D. Willig, New York: North- Holland, 1989. 
Conway, P., Janod, V. and G. Nicoletti (2005) "Product market regulation in OECD countries; 1998 to 2003" OECD Economics Department Working Papers No. 419 ECO/WKP(2005)6.

EC (1996) Commission Communication on the Impact and Effectiveness of the Single Market presented to the Dublin European Council, 13-14 December 1996, http://europa.eu.int/comm./internal_market/en/update/impact/singleen.pdf

EU (2003) "An agenda for a growing Europe: making the EU economic system deliver" Report of an Independent High-Level Study group established on the initiative of the President of the European Commission, July 2003.

Gilbert and Newbery (1982) "Preemptive Patenting and the Persistence of Monopoly," American Economic Review, vol. 72(3), pages 514-26.

Griffith, R., Redding, S. and J. Van Reenen (2004) "Mapping the Two Faces of R\&D: Productivity Growth in a Panel of OECD Manufacturing Industries", Review of Economics and Statistics, November 2004

Griliches, Z. (1979), "Issues in assessing the contribution of research and development to productivity growth”, Bell Journal of Economics 10 (1), 92-1167.

Grossman and Helpman (1991) "Quality Ladders in the Theory of Growth" Review of Economic Studies Vol 58, Issue 1, 43-61

Hall R. E. (1988) “The relationship between price and marginal cost in U.S. industry” Journal of Political Economy, vol. 96, 921-47.

Harrigan, J. (1997) “Technology, Factor Supplies and International Specialization” American Economic Review, 87, 475-94.

Hart, O. (1983) “The market mechanism as an incentive scheme,” Bell Journal of Economics, 14 (Autumn 1983), 366-382

Howitt P. (2000) "Endogenous Growth and Cross-country Income Differences”, American Economic Review, 90(4), 829-46.

Imbens, G. and Angrist, J.(1994) "Identification and estimation of local average treatment effects”, Econometrica, 62, 467-475

Javorcik, B. (2004) "Does Foreign Direct Investment Increase the Productivity of Domestic Firms", American Economic Review, 94(3), 605-627.

Klette, T. (1999) "Market Power, Scale Economies and Productivity: Estimates from a Panel of Establishment Data” The Journal of Industrial Economics December 1999, 451-476.

Mayes and Hart (1994), The Single Market Programme as a Stimulus to Change, Cambridge University Press.

Nickell, S. (1996) "Competition and Corporate Performance", Journal of Political Economy, 104, 724-746.

Nicoletti, G and Scarpetta, S (2004) "Regulation, productivity and growth: OECD evidence" Economic Policy, April 2004, 9-72.

Olley, S and Pakes, A. (1996), "The Dynamics of Productivity in the Telecommunications Equipment Industry”, Econometrica, 64(6), 1263-98.

Pavcnik, N. (2002) “Trade Liberalization, Exit and Productivity Improvements: Evidence from Chilean Plants”, The Review of Economic Studies, 69, 245-76.

Roeger, W. (1995) "Can Imperfect Competition Explain the Difference Between Primal and Dual Productivity Measures? Estimates for US Manufacturing” Journal of Political Economy 103, 316-330.

Schmidt (1997) "Managerial Incentives and Product Market Competition" Review of Economic Studies Vol 64, Issue 2, 191-213.

Stock, J. and M. Yogo (2004), “Testing for weak instruments in Linear IV regression”, Department of Economics, Harvard University, mimeo

Tirole, J (1998) The Theory of Industrial Organization Cambridge, MA: MIT Press. 
Table 1: Single Market Programme: average \% of 2-digit industry falling into the different affected groups

\begin{tabular}{|c|c|c|c|c|c|}
\hline \multirow{2}{*}{ \% of employment falling into Group: } & SMP Group 1 & SMP Group 2 & SMP Group 3 & SMP Group 4 & $\begin{array}{l}\text { Unaffected } \\
\text { sectors }\end{array}$ \\
\hline & $\begin{array}{c}\text { High-tech, public } \\
\text { procurement markets }\end{array}$ & $\begin{array}{l}\text { Traditional public } \\
\text { procurement and } \\
\text { regulated markets } \\
\text { (high price } \\
\text { dispersion) }\end{array}$ & $\begin{array}{c}\text { Traditional public } \\
\text { procurement and } \\
\text { regulated markets } \\
\text { (low price } \\
\text { dispersion) }\end{array}$ & $\begin{array}{c}\text { Moderately affected } \\
\text { sectors }\end{array}$ & \\
\hline
\end{tabular}

\section{Industries in SMP countries}

15-16: Food, beverages and tobacco

17-19: Textiles, leather and footwear

21-22: Pulp, paper, printing and publishing

23: Coke, petroleum and nuclear fuel

24: Chemicals and chemical products

25: Rubber and plastics

26: Other non-metallic minerals

27: Basic metals

28: Metal products

$\begin{array}{cc}0 & 9.1 \\ 0 & 0 \\ 0 & 0 \\ 0 & 0 \\ 0 & 31.1 \\ 0 & 0 \\ 0 & 0 \\ 0 & 0 \\ 0 & 6.4 \\ 32.0 & 0 \\ 0 & 0 \\ 0 & 7.0\end{array}$

7.4
0
0
0
0
0
0
0
0
11.3
0
27.8

$\begin{array}{cc}0 & 83.4 \\ 62.4 & 37.6 \\ 0 & 100 \\ 0 & 100 \\ 59.8 & 9.1 \\ 26.1 & 73.9 \\ 40.4 & 59.6 \\ 0 & 100 \\ 0 & 93.6 \\ 39.3 & 17.3 \\ 97.4 & 2.6 \\ 38.1 & 27.0\end{array}$

All industries in non-SMP countries

0

$\mathbf{0}$

0

0

100

Notes: the SMP countries in the sample are Belgium, Denmark, France, the Netherlands and the UK. The non-SMP countries are Canada, Finland, Norway and the USA. 
Table 2: Descriptive Statistics

\begin{tabular}{|c|c|c|c|c|c|}
\hline & $\begin{array}{l}\text { Profitability } \\
\text { (standard } \\
\text { deviation) }\end{array}$ & $\begin{array}{c}\text { R\&D intensity } \\
\text { (standard } \\
\text { deviation) }\end{array}$ & $\begin{array}{c}\text { In real R\&D } \\
\text { expenditure } \\
\text { (standard } \\
\text { deviation) }\end{array}$ & $\begin{array}{l}\text { Growth in } \\
\text { TFP } \\
\text { (standard } \\
\text { deviation) }\end{array}$ & $\begin{array}{c}\text { Number of } \\
\text { observations }\end{array}$ \\
\hline Belgium & $\begin{array}{c}1.214 \\
(0.169)\end{array}$ & $\begin{array}{c}0.051 \\
(0.050)\end{array}$ & $\begin{array}{c}4.489 \\
(1.396)\end{array}$ & $\begin{array}{c}0.011 \\
(0.091)\end{array}$ & 95 \\
\hline Canada & $\begin{array}{c}1.314 \\
(0.231)\end{array}$ & $\begin{array}{c}0.033 \\
(0.049)\end{array}$ & $\begin{array}{c}4.892 \\
(1.409)\end{array}$ & $\begin{array}{c}0.021 \\
(0.050)\end{array}$ & 161 \\
\hline Denmark & $\begin{array}{c}1.128 \\
(0.076)\end{array}$ & $\begin{array}{c}0.043 \\
(0.058)\end{array}$ & $\begin{array}{c}5.331 \\
(1.853)\end{array}$ & $\begin{array}{c}0.010 \\
(0.064)\end{array}$ & 91 \\
\hline Finland & $\begin{array}{c}1.199 \\
(0.197)\end{array}$ & $\begin{array}{c}0.050 \\
(0.042)\end{array}$ & $\begin{array}{c}3.601 \\
(1.234)\end{array}$ & $\begin{array}{c}0.029 \\
(0.064)\end{array}$ & 140 \\
\hline France & $\begin{array}{c}1.213 \\
(0.186)\end{array}$ & $\begin{array}{c}0.105 \\
(0.160)\end{array}$ & $\begin{array}{c}5.978 \\
(1.230)\end{array}$ & $\begin{array}{c}0.016 \\
(0.097)\end{array}$ & 82 \\
\hline United Kingdom & $\begin{array}{c}1.146 \\
(0.117)\end{array}$ & $\begin{array}{c}0.061 \\
(0.065)\end{array}$ & $\begin{array}{c}5.435 \\
(1.556)\end{array}$ & $\begin{array}{c}0.020 \\
(0.050)\end{array}$ & 150 \\
\hline Netherlands & $\begin{array}{c}1.248 \\
(0.161)\end{array}$ & $\begin{array}{c}0.041 \\
(0.050)\end{array}$ & $\begin{array}{c}4.126 \\
(1.686)\end{array}$ & $\begin{array}{c}0.012 \\
(0.065)\end{array}$ & 136 \\
\hline Norway & $\begin{array}{c}1.053 \\
(0.107)\end{array}$ & $\begin{array}{c}0.041 \\
(0.043)\end{array}$ & $\begin{array}{c}5.045 \\
(1.380)\end{array}$ & $\begin{array}{c}0.007 \\
(0.061)\end{array}$ & 108 \\
\hline United States & $\begin{array}{c}1.241 \\
(0.200)\end{array}$ & $\begin{array}{c}0.078 \\
(0.099)\end{array}$ & $\begin{array}{c}7.967 \\
(1.615)\end{array}$ & $\begin{array}{c}0.016 \\
(0.058)\end{array}$ & 154 \\
\hline Total & $\begin{array}{c}1.203 \\
(0.187)\end{array}$ & $\begin{array}{c}0.055 \\
(0.075)\end{array}$ & $\begin{array}{c}5.228 \\
(1.963)\end{array}$ & $\begin{array}{c}0.017 \\
(0.065)\end{array}$ & 1117 \\
\hline
\end{tabular}

\footnotetext{
Notes: The sample consists of an unbalanced panel of 12 two-digit industries over 9 countries for the period 1987-2000. Profitability is as specified in equation (5). R\&D is Business Enterprise Research and Development (BERD). Growth in TFP is as specified in equation (6).
} 
Table 3: First stage reduced form: profitability and the SMP

\begin{tabular}{|c|c|c|c|}
\hline Dep. var.: profitability & $\begin{array}{l}\text { (1) } \\
\text { Full sample }\end{array}$ & $\begin{array}{c}\text { (2) } \\
\text { Full sample }\end{array}$ & $\begin{array}{c}\text { (3) } \\
\text { SMP countries only }\end{array}$ \\
\hline SMP Group 1 & $\begin{array}{l}-0.173 \\
(0.122)\end{array}$ & $\begin{array}{l}-0.247 \\
(0.162)\end{array}$ & $\begin{array}{l}-0.163 \\
(0.174)\end{array}$ \\
\hline SMP Group 2 & $\begin{array}{c}-0.295 \\
(0.110)^{* * *}\end{array}$ & $\begin{array}{c}-0.358 \\
(0.102)^{* * *}\end{array}$ & $\begin{array}{l}-0.050 \\
(0.090)\end{array}$ \\
\hline SMP Group 3 & $\begin{array}{l}-0.042 \\
(0.181)\end{array}$ & $\begin{array}{l}-0.273 \\
(0.210)\end{array}$ & $\begin{array}{l}-0.220 \\
(0.304)\end{array}$ \\
\hline SMP Group 4 & $\begin{array}{c}-0.109 \\
(0.032)^{* * *}\end{array}$ & $\begin{array}{c}-0.137 \\
(0.040)^{* * *}\end{array}$ & $\begin{array}{c}-0.157 \\
(0.053)^{* * *}\end{array}$ \\
\hline Country dummies & Yes & No & No \\
\hline Industry dummies & Yes & No & No \\
\hline Year dummies & Yes & No & No \\
\hline Country-year dummies & No & Yes & Yes \\
\hline Industry-year dummies & No & Yes & Yes \\
\hline F-statistic & 10.85 & 12.25 & 2.74 \\
\hline Partial R-squared & 0.039 & 0.051 & 0.027 \\
\hline Observations & 1117 & 1117 & 554 \\
\hline R-squared & 0.49 & 0.59 & 0.58 \\
\hline
\end{tabular}

Notes: Robust Newey-West standard errors in brackets with maximum lag length set to 3; the sample in columns (1) and (2) consists of 12 two-digit industries or groups of industries across 9 countries (5 are SMP countries - Belgium, Denmark, France, the Netherlands and the UK - and 4 are non-SMP countries - Canada, Finland, Norway and the USA) over the years 1987-2000. In column (3) only the 5 SMP countries are included.

F-statistic is a test of the joint significance of the SMP variables. The partial R-squared is for the SMP variables.

*,** and *** indicate significance at $10 \%, 5 \%$ and $1 \%$ levels respectively.

SMP Group 1: High-tech, public procurement markets; SMP Group 2:Traditional public procurement and regulated markets (high price dispersion); SMP Group 3: Traditional public procurement and regulated markets (low price dispersion);SMP Group 4: Moderately affected sectors. 
Table 4: R\&D intensity

\begin{tabular}{|c|c|c|c|c|}
\hline Dep. var.: R\&D/VA & $\begin{array}{c}\text { (1) } \\
\text { OLS }\end{array}$ & $\begin{array}{l}\text { (2) } \\
\text { IV }\end{array}$ & $\begin{array}{l}\text { (3) } \\
\text { IV }\end{array}$ & $\begin{array}{c}\text { (4) } \\
\text { Reduced Form }\end{array}$ \\
\hline Profitability & $\begin{array}{c}-0.073 \\
(0.024)^{* * *}\end{array}$ & $\begin{array}{c}-0.295 \\
(0.088)^{* * *}\end{array}$ & $\begin{array}{c}-0.452 \\
(0.114)^{* * *}\end{array}$ & \\
\hline SMP Group 1 & & & $\begin{array}{c}-0.245 \\
(0.091)^{* * *}\end{array}$ & $\begin{array}{c}-0.190 \\
(0.064) * * *\end{array}$ \\
\hline SMP Group 2 & & & & $\begin{array}{c}0.163 \\
(0.031)^{* * *}\end{array}$ \\
\hline SMP Group 3 & & & & $\begin{array}{c}0.347 \\
(0.147)^{* *}\end{array}$ \\
\hline SMP Group 4 & & & & $\begin{array}{c}0.063 \\
(0.018)^{* * *}\end{array}$ \\
\hline Country-year dummies & Yes & Yes & Yes & Yes \\
\hline Industry-year dummies & Yes & Yes & Yes & Yes \\
\hline F-statistic & - & 12.25 & 13.11 & - \\
\hline Partial R-squared & - & 0.051 & 0.042 & - \\
\hline $\begin{array}{l}\text { Hansen J test } \\
\text { (p-value) }\end{array}$ & - & $\begin{array}{c}11.93 \\
(0.008)\end{array}$ & $\begin{array}{c}2.27 \\
(0.322)\end{array}$ & - \\
\hline Observations & 1117 & 1117 & 1117 & 1117 \\
\hline R-squared & 0.67 & 0.64 & 0.64 & 0.69 \\
\hline
\end{tabular}

Notes: Robust Newey-West standard errors in brackets with maximum lag length set to 3; the sample consists of 12 two-digit industries or groups of industries across 9 countries over the period 19872000.

F-statistic is a test of the joint significance of the excluded SMP variables in the first stage regression; the partial R-squared is for the SMP variables in the first stage regression (see Table 3). The Hansen $J$ test is a test of the exclusion restrictions.

$*$, ** and $* * *$ indicate significance at $10 \%, 5 \%$ and $1 \%$ levels respectively.

SMP Group 1: High-tech, public procurement markets; SMP Group 2:Traditional public procurement and regulated markets (high price dispersion); SMP Group 3: Traditional public procurement and regulated markets (low price dispersion); SMP Group 4: Moderately affected sectors 
Table 5: Log real R\&D

\begin{tabular}{|c|c|c|c|c|}
\hline Dep. var.: $\ln (\mathrm{R} \& D)$ & $\begin{array}{c}\text { (1) } \\
\text { OLS }\end{array}$ & $\begin{array}{l}\text { (2) } \\
\text { IV }\end{array}$ & $\begin{array}{l}\text { (3) } \\
\text { IV }\end{array}$ & $\begin{array}{c}\text { (4) } \\
\text { Reduced Form }\end{array}$ \\
\hline Profitability & $\begin{array}{c}-0.522 \\
(0.298)^{*}\end{array}$ & $\begin{array}{c}-4.790 \\
(0.991)^{* * *}\end{array}$ & $\begin{array}{c}-5.901 \\
(1.302)^{* * *}\end{array}$ & \\
\hline SMP Group 1 & & & $\begin{array}{c}-3.318 \\
(1.255)^{* * *}\end{array}$ & $\begin{array}{c}-2.028 \\
(0.643)^{* * *}\end{array}$ \\
\hline SMP Group 2 & & & & $\begin{array}{c}1.522 \\
(0.481)^{* * *}\end{array}$ \\
\hline SMP Group 3 & & & & $\begin{array}{c}1.898 \\
(1.190)\end{array}$ \\
\hline SMP Group 4 & & & & $\begin{array}{c}1.149 \\
(0.231)^{* * *}\end{array}$ \\
\hline Country-year dummies & Yes & Yes & Yes & Yes \\
\hline Industry-year dummies & Yes & Yes & Yes & Yes \\
\hline F-statistic & - & 12.25 & 13.11 & - \\
\hline Partial R-squared & - & 0.051 & 0.042 & - \\
\hline $\begin{array}{l}\text { Hansen J test } \\
\text { (p-value) }\end{array}$ & - & $\begin{array}{c}11.85 \\
(0.008)\end{array}$ & $\begin{array}{c}1.66 \\
(0.436)\end{array}$ & - \\
\hline Observations & 1117 & 1117 & 1117 & 1117 \\
\hline R-squared & 0.89 & 0.85 & 0.83 & 0.90 \\
\hline
\end{tabular}

Notes: Robust Newey-West standard errors in brackets with maximum lag length set to 3; the sample consists of 12 two-digit industries or groups of industries across 9 countries over the period 19872000.

F-statistic is a test of the joint significance of the excluded SMP variables in the first stage regression; the partial R-squared is for the SMP variables in the first stage regression (see Table 3). The Hansen $J$ test is a test of the exclusion restrictions.

$*$, ** and $* * *$ indicate significance at $10 \%, 5 \%$ and $1 \%$ levels respectively.

SMP Group 1: High-tech, public procurement markets; SMP Group 2:Traditional public procurement and regulated markets (high price dispersion); SMP Group 3: Traditional public procurement and regulated markets (low price dispersion); SMP Group 4: Moderately affected sectors 
Table 6: R\&D intensity, SMP countries only

\begin{tabular}{|c|c|c|c|c|}
\hline Dep. var.: R\&D/VA & $\begin{array}{c}(1) \\
\text { OLS }\end{array}$ & $\begin{array}{l}\text { (2) } \\
\text { IV }\end{array}$ & $\begin{array}{l}\text { (3) } \\
\text { IV }\end{array}$ & $\begin{array}{c}\text { (4) } \\
\text { Reduced Form }\end{array}$ \\
\hline Profitability & $\begin{array}{c}-0.124 \\
(0.034)^{* * *}\end{array}$ & $\begin{array}{c}-0.474 \\
(0.141)^{* * *}\end{array}$ & $\begin{array}{c}-0.435 \\
(0.135)^{* * *}\end{array}$ & \\
\hline SMP Group 1 & & & & $\begin{array}{c}0.126 \\
(0.056)^{* *}\end{array}$ \\
\hline SMP Group 2 & & & $\begin{array}{c}0.128 \\
(0.052)^{* *}\end{array}$ & $\begin{array}{c}0.146 \\
(0.045)^{* * *}\end{array}$ \\
\hline SMP Group 3 & & & & $\begin{array}{l}-0.225 \\
(0.240)\end{array}$ \\
\hline SMP Group 4 & & & & $\begin{array}{c}0.063 \\
(0.037)^{*}\end{array}$ \\
\hline Country-year dummies & Yes & Yes & Yes & Yes \\
\hline Industry-year dummies & Yes & Yes & Yes & Yes \\
\hline F-statistic & - & 2.74 & 3.63 & - \\
\hline Partial R-squared & - & 0.027 & 0.026 & - \\
\hline $\begin{array}{l}\text { Hansen J test } \\
\text { (p-value) }\end{array}$ & - & $\begin{array}{c}8.18 \\
(0.042)\end{array}$ & $\begin{array}{c}4.37 \\
(0.112)\end{array}$ & - \\
\hline Observations & 554 & 554 & 554 & 554 \\
\hline R-squared & 0.85 & 0.77 & 0.79 & 0.85 \\
\hline
\end{tabular}

Notes: Robust Newey-West standard errors in brackets with maximum lag length set to 3; the sample consists of 12 two-digit industries or groups of industries across 9 countries over the period 19872000.

F-statistic is a test of the joint significance of the excluded SMP variables in the first stage regression; the partial R-squared is for the SMP variables in the first stage regression (see Table 3). The Hansen $J$ test is a test of the exclusion restrictions.

$*$, ** and $* * *$ indicate significance at $10 \%, 5 \%$ and $1 \%$ levels respectively.

SMP Group 1: High-tech, public procurement markets; SMP Group 2:Traditional public procurement and regulated markets (high price dispersion); SMP Group 3: Traditional public procurement and regulated markets (low price dispersion); SMP Group 4: Moderately affected sectors 
Table 7: TFP growth

\begin{tabular}{|c|c|c|c|c|c|}
\hline Dep Var.: TFP growth & $\begin{array}{l}\text { (1) } \\
\text { OLS }\end{array}$ & $\begin{array}{l}\text { (2) } \\
\text { IV }\end{array}$ & $\begin{array}{c}\text { (3) } \\
\text { OLS }\end{array}$ & $\begin{array}{l}\text { (4) } \\
\text { IV }\end{array}$ & $\begin{array}{c}\text { (5) } \\
\text { Reduced form }\end{array}$ \\
\hline R\&D/VA & $\begin{array}{c}0.119 \\
(0.036)^{* * *}\end{array}$ & $\begin{array}{c}0.598 \\
(0.149)^{* * *}\end{array}$ & $\begin{array}{c}0.075 \\
(0.034)^{* *}\end{array}$ & $\begin{array}{c}0.802 \\
(0.255)^{* * *}\end{array}$ & \\
\hline Profitability & & & $\begin{array}{c}-0.085 \\
(0.013)^{* * *}\end{array}$ & $\begin{array}{c}0.084 \\
(0.091)\end{array}$ & \\
\hline Distance to frontier & $\begin{array}{c}0.037 \\
(0.007)^{* * *}\end{array}$ & $\begin{array}{c}0.055 \\
(0.010)^{* * *}\end{array}$ & $\begin{array}{c}0.044 \\
(0.007)^{* * *}\end{array}$ & $\begin{array}{c}0.053 \\
(0.012)^{* * *}\end{array}$ & $\begin{array}{c}0.034 \\
(0.007)^{* * *}\end{array}$ \\
\hline SMP Group 1 & & & & & $\begin{array}{c}-0.120 \\
(0.034)^{* * *}\end{array}$ \\
\hline SMP Group 2 & & & & & $\begin{array}{c}0.078 \\
(0.033)^{* *}\end{array}$ \\
\hline SMP Group 3 & & & & & $\begin{array}{c}0.050 \\
(0.050)\end{array}$ \\
\hline SMP Group 4 & & & & & $\begin{array}{c}0.017 \\
(0.011)\end{array}$ \\
\hline Country-year dummies & Yes & Yes & Yes & Yes & Yes \\
\hline Industry-year dummies & Yes & Yes & Yes & Yes & Yes \\
\hline F-statistic & - & 11.11 & - & 4.50 & - \\
\hline Partial R-squared (1) & - & 0.052 & - & 0.033 & - \\
\hline Partial R-squared (2) & - & - & - & 0.028 & - \\
\hline $\begin{array}{l}\text { Hansen J test } \\
\text { (p-value) }\end{array}$ & - & $\begin{array}{c}1.76 \\
(0.624)\end{array}$ & - & $\begin{array}{c}0.65 \\
(0.723)\end{array}$ & - \\
\hline Observations & 1008 & 1008 & 1008 & 1008 & 1008 \\
\hline R-squared & 0.42 & 0.47 & 0.46 & 0.46 & 0.43 \\
\hline
\end{tabular}

Notes: Robust Newey-West standard errors in brackets with maximum lag length set to 3; the sample consists of 12 two-digit industries or groups of industries across 9 countries over the period 19882000.

F-statistic is the Cragg-Donald F-statistic, a measure of the power of the excluded SMP variables in the first stage regressions; the partial R-squareds are for the SMP variables in the first stage regressions for $R \& D$ intensity and profitability respectively. The Hansen $J$ test is a test of the exclusion restrictions.

*,** and *** indicate significance at $10 \%, 5 \%$ and $1 \%$ levels respectively.

SMP Group 1: High-tech, public procurement markets; SMP Group 2:Traditional public procurement and regulated markets (high price dispersion); SMP Group 3: Traditional public procurement and regulated markets (low price dispersion); SMP Group 4: Moderately affected sectors 